\title{
THE ROLE OF MANAGER'S LOCUS OF CONTROL BETWEEN PERCEIVED GUANXI AND LEADERSHIP BEHAVIOR IN FAMILY BUSINESS
}

\author{
EL PAPEL DEL LOCUS DE CONTROL DEL JEFE ENTRE EL GUANXI \\ PERCIBIDO Y LA CONDUCTA DE LIDERAZGO EN LOS NEGOCIOS \\ FAMILIARES
}

\author{
TuNG-Ju Wu d98410004@gmail.com \\ College of Business Administration. Huaqiao University. China.
}

Hsien-TANG Tsal htt@mail.nsysu.edu.tw

Department of Business Management. National Sun Yat-sen University. Kaohsiung. Taiwan.

Shang-PaO YeH Shangpao@ms12.hinet.net

Department of Tourism. I-Shou University. Kaohsiung. Taiwan.

\begin{abstract}
The special and historical relationship network in Chinese societies is based on blood ties or family emotional connection, in which family business appears the best representative. With the specialty of corporate structure, power and leadership between superiors and subordinates are the critical issues for research, where managers' personality is particularly emphasized. We combine guanxi in Chinese societies, power, influence tactics, and locus of control in the research model, 147 family business in Taiwan are proceeded the questionnaire survey, and 332 valid copies are retrieved. With hierarchical regression analysis, the findings show the close relations between managers' power, perceived guanxi and leadership behavior, in which managers' locus of control play a critical role. It is therefore suggested that the assignation of managers in such type of enterprises should be more cautious; in addition to the communication with the subordinates, the fitness with personality and competence should be concerned in order to maintain the favorable work efficiency and the relations between superiors and subordinates.
\end{abstract}

\section{KEYWORDS}

Influence tactics; Locus of control; Perceived guanxi; Power based.

\section{RESUMEN}

La histórica y especial red de relaciones de la sociedad china se basa en lazos de sangre o en conexiones familiares emocionales de las que los negocios familiares son la mejor representación. Junto con la especialización de las estructuras corporativas, la cuestión clave de esta investigación será el poder y el liderazgo de los jefes sobre los subordinados, poniendo el énfasis en la personalidad del jefe. En el modelo de investigación -administración de un cuestionario a 147 negocios familiares de Taiwán, de los que 332 fueron válidos- combinamos el "guanxi" de las sociedades chinas, el poder, las tácticas para tener influencia y el locus de control. Mediante análisis jerárquicos de regresión los resultados muestran la estrecha relación que se da entre el poder de los jefes, el "guanxi" percibido y la conducta de liderazgo, en la que el locus de control de los jefes desempeña un papel destacado. Por eso se recomienda que la designación de jefes en esas empresas sea más cuidadosa. Además de la comunicación con los subordinados, debe prestarse atención a la adecuación entre personalidad y la competencia para mantener una eficiencia laboral y unas relaciones entre jefes y subordinados favorables.

Palabras clave

Bases del poder; Guanxi percibido; Locus de control; Tácticas de influencia. 


\section{INTRODUCTION}

The relationship network based on blood ties or family emotional connection in Chinese societies is a special and historical type, where family business is the best representative. Family business played the primary role during the economic development in Taiwan. According to the statistics of Ministry of Economic Affairs in 2012, more than $80 \%$ small and medium enterprises in Taiwan are family-operated. Moreover, the core stock right of more than 30 corporations in the top 50 corporations in Taiwan is controlled by the family members (China Credit Information Service 2010). Apparently, family business play a critical role in the economy in Taiwan.

Family business show a special corporate governance model (Miller and Le BretonMiller 2006), as the family members do not simply involve in the businesses from the right of management and ownership, but the identity among members and the external connection contain the unique social capitals of the family (Arregle, Hitt, Sirmon and Very 2007). Such social capitals are the specific networking in Chinese societies, guanxi. guanxi was classified into family ties, friendship, and stakeholder relationship in the past literatures (Hwang 1987; Zhang and Li 2003; Taormina and Gao 2010; Tsai, Wu and Yeh 2013). Nevertheless, not all managers were undertaken by family members that perceived guanxi would be distinct among managers in an enterprise. More importantly, such guanxi is inheritable and continued. Since family business is changing to professional management by employing professional managers, such type of enterprises would appear dual-system organizations. Most high-level decision managers are family members or pan-family members based on family guanxi based on blood ties and marriage predestination, while middle-level or fist-level superiors are composed of nonfamily members like acquainted friends and professional managers, where the enterprise system is established based on professional capabilities and technological talents.

In order to achieve the tasks, managers require sufficient power to lead the subordinates and employees. Enterprises therefore would empower managers with formal and necessary power according to the structure in order to complete the tasks. Managers in enterprises would adopt certain actions to influence subordinates' behaviors on achieving work objectives or completing tasks to present the leadership. Managers often utilized influence tactics, which request the others for following the ideas and demands, for leading the subordinates (Durbin 2001; Tsai et al. 2013). Such a method could affect superiors, peers, or subordinates' behaviors and further change the attitudes, value, belief, or behaviors. Managers would lead and correct the others' behaviors with influence tactics, such as setting an example, order, and persuasion, to achieve the daily work and the permanent objectives of the organization. More importantly, managers' influence tactics are the key factors in the leadership efficiency, as they could determine the success of Leadership and immediately respond to the team or organizational performance.

O'Reilly (1977) proposed the idea of Personality-Work Fit, indicating that people with different personality traits would change the job performance on certain job cha- 
racteristics. In this case, they would present distinct performance on the same working environment because of individual personality traits and various job competences. Traditional trait theory regards personality traits being innate, while situationists consider the effects of extrinsic environmental on changing personality traits. However, understanding organization members' personality tendency and the interactive behaviors in the organization is the best way to find the job performance. This study aims to discuss the effects of managers' power and perceived guanxi on leadership behavior in family business. Furthermore, the moderating effects of locus of control on the correlations among manager' power, perceived guanxi, and leadership behavior are explored.

\section{LITERATURE REVIEW AND HYPOTHESIS}

\section{Influence Tactics}

Influence refers to persuading others into believing or engaging in specific behaviors that leadership management functions to influence the other members in an organization. Nevertheless, such a single factor could not solve or complete the organizational tasks that managers have to apply various skills, including the applications of interpersonal and political relationship, to reaching the purpose. The behaviors or movements of managers influencing the others are called Influence Tactics, indicating how power owners transform power into specific movements to acquire the desired objects (Kipnis et al. 1980; Hinkin and Schriesheim 1989). Yukl and Falbe (1990) regarded influence as the key factor in linking power and the desired objective, i.e. the bridge to transform power into specific movements. Besides, the practice of influence tactics in an organization would be different according to the influence intention and the practice objectives; and the influence target could be classified into upward, lateral, and downward.

In such a special enterprise style, the subordinates' work and living are deeply influenced by the supervisor in family business that distinct work efficiency and behaviors are presented. In comparison with horizontal colleague relationship, the vertical relationship between supervisor and subordinates is more important. In general, one or more influence tactics would be used, according to the objects. Kipnis et al. (1980) and Schriesheim and Hinkin (1990) divided influence tactics into 1.Ingratiation: showing friendliness before requests, 2.Exchange: exchanging the desired benefits, 3.Rationality: proposing logical and rational opinions based on facts, 4.Assertiveness: applying direct and tough styles, like ordering others to follow the rules, 5.Upward Appeals: looking for the assistance of superior managers, and 6.Coalition: searching for support from other staff in the organization. Yukl et al. (1990) discovered that supervisor often influenced the subordinates with rationality, while pressure and coalition appeared the least efficiency. 


\section{Power}

French and Raven (1959) considered power as the ability of a party influencing and changing the decisions of the other party. In terms of resource-based view, power could be regarded as personal unique resources, as a person could control the others when he/she could control and dominate the others' resources. For this reason, the one with power normally would undertake the key position in an organization that the power in an enterprise is generally top-down relationship. Power is based on the acquisition of resources that people with power are specific ones, as the power could further control and influence the others' lives, behaviors, and attitudes. Finkelstein (1992) mentioned that the application of power played the critical role in making strategic decisions, as some managers would share the power and responsibilities with the members through empowerment (Conger and Kanungo 1987; Holpp 1994) so as to show the commitment and trust to the subordinates.

Power is personal abilities given by the organization, which could change, dominate, or order the others' behaviors. French and Raven (1959) described managers' leadership behavior based on the power of 1.Legitimate: the individual formal power given by the organization because of the position, 2.Reward: the power distributing valuable rewards to the others, 3.Coercive: the power giving the others with undesired affairs or punishment, 4.Expert: the acquired power from special skills or knowledge, and 5.Referent: the power resulted from the unique personality, which the subordinates were willing to obey. Rosenberg and Pearlin (1962) found that the applications of power would change with managers' positions and tenure; more experienced organization members and managers preferred applying legitimate and referent to the interpersonal relationship. Researchers further considered that expert and referent were the exclusive power from personal traits, while legitimate, reward, and position were the formal power given by the organization. The five types of power therefore were divided into position power and personal power (Robbins 2001; Yukl 2002).

Brass and Burkhardt (1993) proposed the obvious correlations between organizational structure, influence behaviors and power that the applications of power were the correspondent relationship to individual positions and behaviors. In Yukl's (2002) power and influence model, leaders would select influence tactics according to the objects, and the owned power would reinforce the influence intention. For this reason, power and influence behavior in leadership strategies reveal significant correlations, i.e. managers' perceive power would affect leadership behavior. As each manger appears various abilities and positions, the required power is distinct that the leadership and management styles would be different. An enterprise therefore would give proper power according to the requirements. For instance, managers with higher position power would treat the subordinates more toughly. In this case, H1a: Position power shows positive relations with assertiveness and upward appeals and $\mathrm{H} 1 \mathrm{~b}$ : Personal power reveals positive relations with ingratiation, exchange, rationality, and coalition is proposed. 


\section{Perceived Guanxi}

The connection among people is called guanxi in China, which is a special emotional culture in Chinese societies. Guanxi, a specific style in Chinese societies, is similar to the interpersonal relationship in social network. In the past two thousand years, the value of collectivism and order was repeated in Chinese culture and reflected on the social and commercial activities of Chinese people. Confucianism provided individuals the role orientation in the society and the behavioral rules to get along with others. Such a basic principle is called guanxi or interpersonal relationship (Hwang 1987), which becomes the value of interpersonal relationship in Chinese societies. Yang (1994) broadly studied guanxi and defined it as the correlations among objects, forces, or persons; guanxi was not simply applied to marital relationship, kinship, and friendship, but focused on the correlations among people that it was regarded as a type of social connection; the relationship among the two revealed that guanxi was mainly established on common benefits and profits. Guanxi provides Chinese people with living and economic or political convenience (Gold, Guthries and Wank, 2002; Tsai, Yeh and Wu 2011).

Living in Chinese societies with such a complicated relationship network, it is often used for measuring the value of a person (Yang 2000). Lee and Dawes (2005) studied the enterprises marketing in China who proposed the applications of such chaxugeju to establishing guanxi, trust, and orientation and indicated that guanxi in China mostly indicated to connect with a network through a channel. The importance of guanxi would change with personal emphases. Jacobs (1979) pointed out the major connection of guanxi including blood ties (marital relationship, direct or collateral relatives), geo-relation, classmates, colleagues, friendship, sworn relationship, and even teacher-student relationship. Such guanxi was not necessary directly connected that the establishment was not certainly based on real relationship, but presenting closer relationship through reciprocals, to achieve the advantageous objects. Renqing and mianzi, as the key factors in guanxi (Lee, Pae and Wong 2001; Lee and Drawes 2005; Zhuang, Xi and Tsang 2010), could connect people without kinship or the ones from different social levels through social interaction, and the affection would be enhanced when the social interaction is continued. For this reason, establishing close relationship with others by assisting them could maintain the close relationship, where reliability and trust are the key factors.

Guanxi in Chinese societies does not simply result in living convenience, but also economic or political convenience (Gold et al. 2002). In family business, managers controlling the key positions or decision-making power are mainly the family trusted followers, including the ones with blood ties, marital relationship, and friendship, that they often bear the family burden when leading the subordinates. In this case, guanxi in such type of enterprises stresses on reciprocals and assistance. Lee et al. (2001) also emphasized guanxi as a special transactional relationship among partners, who acquired benefits by exchanging the preference. As a result, when managers consider the importance of guanxi in the enterprises, he/she is likely to present Friendliness and Coalition, rather than tough strategies on Leadership. $\mathrm{H} 2$ : Perceived guanxi shows positive relations with 
ingratiation, exchange, rationality, upward appeals, and coalition, but negative relations with assertiveness and upward appeals therefore is proposed.

\section{Locus of Control}

According to David and Stanely's (1989) opinions about personality traits, personality, composed of personal characteristics, was the best way to judge the commonality and differences between individuals and others and the sustainable and stable character and tendency. Robbins (2001) considered that personality was shaped by the interaction between nature and environments and learning and affected by situations. Traits were the permanently performed behavioral characteristics. When such characteristics continuously occurred in different situations, they were regarded as personality traits. Consequently, personality traits were the summarized characteristics of an individual reacting and responding to people, affairs, and objects in external environments under the interaction between nature and environments or situations. Locus of Control was proposed in social-learning theory by Rotter (1954), who regarded internal locus of control personality as the occurred events an individual considered, which were caused by personal behaviors, attributes, and abilities, that they could be controlled and predicted by the person. Internal locus of control personality were the behavioral results an individual believed, which were resulted from personal abilities or attributes, that they could be predicted or controlled by the person. External locus of control personality, on the other hand, regarded the occurred events caused by nature and external factors that personal efforts would be useless (Rotter 1966; Brissett and Nowicki 1976; Martin, Thomas, Charles, Epitropaki and Mcnamara 2005). Locus of control would affect work attitudes. Internal locus of control people showed higher job engagement than external locus of control ones did that the job satisfaction was higher (Spector 1982; Pierce and Dunham 1987; Judge and Bono 2001; Meyer, Stanley, Herscovitch and Topolnytsky 2002; Boone and Hendriks 2009; Bernardi 2011).

Comparing the differences between internal locus of control and external locus of control, Spector (1982) discovered that external locus of control people were more obedient than internal locus of control ones that they could easily accept everything offered by the organization. Internal locus of control people believed that hard working could result in success, while failure was personal responsibility; external locus of control ones, on the other hand, did not believe in the relations between success/failure and personal abilities or efforts. Robbins (2001) indicated that internal locus of control people were suitable for complex tasks, such as managerial and professional jobs, which required the abilities to deal with complicated information and highly learning abilities. Furthermore, internal locus of control people were competent of creative and independently operating tasks, while external locus of control ones were more suitable for listening to orders and engaging in routine work or highly regulated and standardized tasks ( $\mathrm{Ng}$ and Feldman 2011). Accordingly, it is considered that managers' locus of control would affect leadership behavior and decision-making that H3: Managers' 
locus of control appears moderating effects on power and leadership behavior is further proposed.

Internal locus of control and external locus of control managers present distinct perception on the working atmosphere that different behaviors are revealed (Furnham and Drakeley 1993). For example, internal locus of control managers are mostly positive and active, while external locus of control ones mainly follow the rules. Besides, internal locus of control people appear higher job satisfaction and lower turnover intention, show more autonomic and self-control ideas, and present longer job planning than external locus of control ones do that they are comparatively friendlier when leading the subordinates (Haybatollahi and Gyekye 2012). Chinese guanxi focuses on renqing and mianzi (Zhuang et al. 2010) but the workers would reveal distinct perception because of various personality traits. H4: Managers' locus of control shows moderating effects on perceived guanxi and leadership behavior is therefore taken into account.

Figure 1.

Model of managers' power and leadership behavior in family business

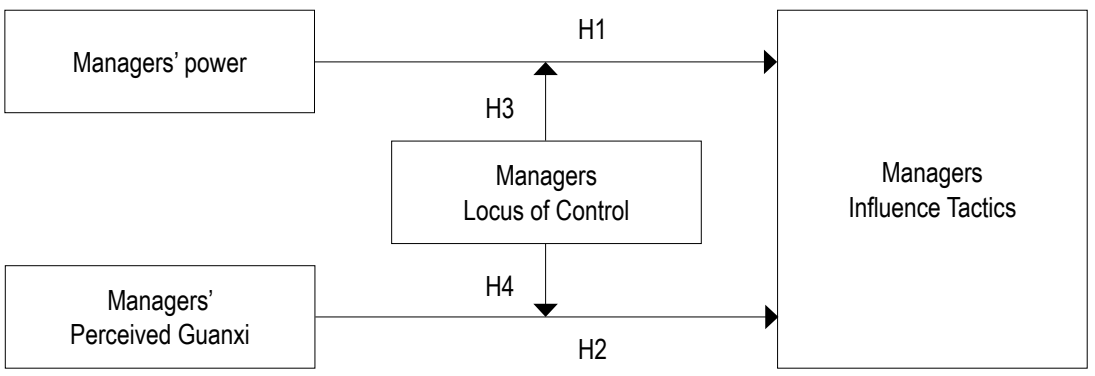

\section{RESEARCH DESIGN}

\section{Research participant}

Managers in family business in Taiwan are selected as the research participants. The definition of family business is divided from the aspects of stock right and management right that merely the enterprises satisfying such two conditions are selected (Tsai et al. 2013). Enterprises with more than $50 \%$ stock right being owned by the family members are included in family business and enterprises with more than two high-level managers with decision-making and leadership being family members is covered in family business. 
The participants are selected in two stages. They are first requested for the intention of interviews through phone calls or emails and then visited for the questionnaire survey. Total 147 family business are each surveyed 2-5 copies of questionnaires, and total 332 valid copies are retrieved. In the samples, 214 of them (or 65 per cent) are males and 118 (or 35 per cent) are females with a mean age of 33.8 years. The mean seniority is 11.3 years. In terms of job position, the samples include high-level managers ( 80 or 24 per cent), middle-level manager (147 or 44 per cent) and first-level manager (105 or 32 per cent); and, a total of 61 per cent of the samples is manufacturers and non-operation units (57 per cent).

\section{Measurement of variable}

\section{(1) Power}

Bases of social power questionnaire, proposed by Hinkin and Schriesheim (1989), is revised and utilized for measuring managers' Power. Total 20 questions are measured with the 5-point scale. Based on Yukl (2002), the five types of power are classified into position power and personal power, and the Cronbach's a appears 0.94 .

\section{(2) Perceived Guanxi}

According to Xin and Pearce's (1996) suggested of guanxi, 6 questions focus on managers' perceived guanxi at the workplace. The 5-point scale is also used for the measurement, and the Cronbach's a reveals 0.97 .

\section{(3) Influence Tactics}

The classification proposed by Kipnis et al. (1980) is utilized for measuring leadership. Total 18 questions are measured with the 5-point scale, and the Cronbach's a show 0.87 .

\section{(4) Locus of Control}

Locus of control scale, proposed by Spector (1988), is applied to measuring managers' Personality Traits. Total 16 questions are measured with the 5-point scale, and the Cronbach's a appears 0.89 .

\section{(5) Control variable}

Referring to the past research on family business, managers' gender, seniority, competence, position, and industry could moderate the research results that they are regarded as the control variables (Kellermanns and Eddleston 2004; Chung 2012), which are further substituted by virtual variables. Regarding the seniority, a decade is considered as 
the boundary that the ones not working for ten years is marked 0 , while the ones working for more than ten years are marked 1. Operation units are considered for the competence that non-operation units, including finance and accounting, personnel and general affairs, information are marked 0 , and operation units, containing production and development and marketing businesses, are marked 1. Middle-level managers are regarded as the baseline of the position that first-level managers are marked 0 , and middle-level managers and above are marked 1 (Tsai et al. 2013).

\section{EMPIRICAL ANALYSIS}

Podsakoff, MacKenzie, Lee and Podsakoff (2003) considered that common method variance (CMV) might confuse the research results. According to the suggestion, Harmen's single-factor analysis was then utilized for testing CMV, and 14 factors were discovered, in which the cumulative variance explained of the first factor appeared $14.73 \%$, not the majority of explanation, that there was no CMV problem in the questionnaires in this study.

With the concepts of hierarchical regression, gender, seniority, position, industry, and competence were regarded as the control variables, power the independent variable, and influence tactics the dependent variable for multiple regression analysis, table 1. With control variables, position power presented significantly positive relations with rationality $(\beta=.294, P<.01)$, assertiveness $(\beta=.512, P<.001)$, and Upward Appeals $(\beta=$ $.129, P<.05)$, but remarkably negative relations with ingratiation $(\beta=-.124, P<.05)$ and exchange $(\beta=-.103, P<.05)$. Moreover, personal power showed notably positive relations with ingratiation $(\beta=.436, P<.001)$, exchange $(\beta=.309, P<.001)$, rationality $(\beta=$ $.477, P<.001)$, upward appeals $(\beta=.437, P<.001)$, and coalition $(\beta=.391, P<.001)$ that H1 was supported.

In regard to the examination of the hypotheses for power and perceived guanxi, perceived guanxi appeared significantly positive relations with ingratiation $(\beta=.397$, $P<.001)$, exchange $(\beta=.346, P<.001)$, rationality $(\beta=.45, P<.001)$, and coalition $(\beta=$ $.462, P<.001)$, but notably negative relations with assertiveness $(\beta=-.319, P<.001)$ and upward appeals ( $\beta=-.453, P<.05)$, table 2 . $\mathrm{H} 2$ therefore was supported.

$\mathrm{H} 3$ and $\mathrm{H} 4$ were verified according to the suggestion of Baron and Kenny (1986). With the effects of managers' Locus of control, Table 3, power revealed partial relations with influence tactics (ingratiation, exchange, upward appeals, and coalition) that $\mathrm{H} 3$ was supported. It was worth mentioning that, in spite of power, external locus of control managers tended to apply upward appeals to the subordinates. With the effects of managers' locus of control, perceived guanxi achieved partial relations with influence tactics (rationality and assertiveness) that $\mathrm{H} 4$ was supported. From table 4 , internal locus of control managers with higher perceived guanxi would not apply assertiveness to the subordinates. 


\section{Conclusion AND SUgGeStION}

Family business is the common style in Chinese societies and plays an important role in economic development. As the key roles in the enterprises are undertaken by the relatives or friends, the governance of family and enterprises, the division of power, and the distribution of organizational duties become critical. This study aims to discuss the correlations between managers' personality and power, perceived guanxi, and influence tactics in family business. Total 332 valid samples are retrieved for hierarchical regression analysis. The results show that managers with distinct power and perceived guanxi would appear different leadership in family business, and managers with various traits would moderate the correlations between them. The research results are expected to provide some suggestions for family business assigning managers in the future.

From the analyses of managers' power, perceived guanxi, and leadership, it is found that managers with more position power are likely to apply assertiveness and upward appeals, rather than ingratiation and exchange, to the subordinates. With the formal power from the enterprises, managers would directly and toughly order the subordinates to complete the tasks, rather than treating with peaceful attitudes. Contrarily, managers with more personal power would use friendly attitudes for influencing the subordinates. As personal power is resulted from personal traits or specialties, managers are likely to lead the subordinates with the specialties that they would influence the subordinates with moral persuasion or friendly attitudes, or assist the subordinates in completing the tasks. It is also found that managers with higher perceived guanxi would not lead the subordinates with assertiveness or upward appeals, as they understand the focus of enterprises being relationship behavior that they would treat the subordinates with more friendly ways so as to smoothly complete the tasks.

Managers' locus of control also reveals moderating effects on power, perceived guanxi, and leadership. External locus of control manager presents more personal power, which shows stronger negative correlations with exchange, upward appeals, or coalition. However, internal locus of control managers with either position power or personal power would appear positive correlations with ingratiation. The past research on locus of control showed that external locus of control people regarded themselves not being able to control the situations so that the personal behaviors were often affected by luck or assisted by others, and not applying constructive actions to dilemmas. In comparison with position power, managers with more personal power would not easily apply coalition or exchange to leading the subordinates completing the tasks, as they agree with "doing the best" and "not insisting" and accept the results. For internal locus of control managers, on the other hand, they could change the situations and believe in achieving the expected results through efforts. For this reason, managers with any types of power believe that they could influence the real environmental or social situations with active behaviors. As the research findings, internal locus of control managers would treat the subordinates with ingratiation and expect the fluent work by interacting with the subordinates. Besides, 
when internal locus of control managers perceive the importance of guanxi, which stresses on renqing and mianzi, in the enterprises, they would tend to lead the subordinates with rationality, expecting to develop and complete tasks with the subordinates so as not to lose the specialties but win mianzi.

Family business is a closed system that the managers play the critical role in the business management. Moreover, guanxi behavior is particularly obvious in family business that managers' perceived guanxi and locus of control are considered as the key factors in leadership behavior. This study concludes that the assignation of managers' positions in such type of enterprises is extremely important; in addition to communicating with the subordinates, the fitness of personality and competence should also be concerned. On one hand, it could easily achieve the organizational objects and enhance the job performance; and on the other hand, it could maintain favorable guanxi between superiors and the subordinates to fluently operate the organization. The follow-up research is suggested to further discuss the effects of various managers' personality traits on subordinates' job performance, job engagement, or turnover tendency. Besides, the superior-subordinate relationship could be included as the moderator to make up the insufficiency in this study.

Table 1.

Manager's power shows positive relations towards subordinates on leadership behavior in family business

\begin{tabular}{|c|c|c|c|c|c|c|c|c|c|c|c|}
\hline \multicolumn{12}{|c|}{ Dependent variables } \\
\hline \multicolumn{2}{|c|}{ Ingratiation } & \multicolumn{2}{|c|}{ Exchange } & \multicolumn{2}{|c|}{ Rationality } & \multicolumn{2}{|c|}{ Assertiveness } & \multicolumn{2}{|c|}{$\begin{array}{l}\text { Upward } \\
\text { appeal }\end{array}$} & \multicolumn{2}{|c|}{ Coalition } \\
\hline M1 & M2 & M1 & M2 & M1 & M2 & M1 & M2 & M1 & M2 & M1 & M2 \\
\hline
\end{tabular}

\begin{tabular}{l|c|c|c|c|c|c|c|c|c|c|c|c}
\hline Gender & .008 & .044 & .001 & .04 & .031 & .076 & -.085 & -.02 & -.063 & -.01 & -.007 & .021 \\
\hline Seniority & $-.175^{*}$ & $-.117^{*}$ & $-.167^{*}$ & -.114 & $-.152^{*}$ & -.072 & -.067 & -.004 & -.079 & -.01 & -.128 & -.074 \\
\hline Job Function & -.001 & -.033 & .013 & .001 & $.156^{*}$ & $.096^{*}$ & .07 & .11 & .013 & .003 & .065 & .018 \\
\hline Industry & -.016 & -.027 & $.128^{*}$ & $.128^{*}$ & $.123^{*}$ & $.099^{*}$ & -.022 & .009 & $.113^{*}$ & $.116^{*}$ & $.116^{*}$ & .096 \\
\hline Job level & .016 & .044 & -.069 & -.003 & -.051 & -.047 & $-.235^{* *}$ & -.033 & .013 & 085 & .059 & .046 \\
\hline
\end{tabular}

\begin{tabular}{l|r|r|r|r|r|r|r|r|r|r|r|c}
\hline Position power & & $-.124^{*}$ & & $-.103^{*}$ & & $.294^{* *}$ & & $.512^{* *}$ & & $.129^{*}$ & & .031 \\
\hline Personal power & & $.436^{* * *}$ & & $.309^{* *}$ & & $.477^{* * *}$ & & .088 & & $.437^{* * *}$ & & $.391^{* * *}$ \\
\hline F values & 2.209 & 18.141 & 3.329 & 14.138 & 2.482 & 57.419 & 3.946 & 22.161 & 1.176 & 21.744 & 1.727 & 18.721 \\
\hline $\mathrm{R}^{2}$ & .018 & .266 & .034 & .217 & .022 & .544 & .043 & .309 & .003 & .305 & .011 & .273 \\
\hline$\Delta \mathrm{R}^{2}$ & & .249 & & .183 & & .517 & & .266 & & .302 & & .262 \\
\hline
\end{tabular}

Note. $\mathrm{N}=332 ;{ }^{*} p<.05 ;{ }^{* *} p<.01 ;{ }^{* * *} p<.001$ 
Table 2.

Manager's perceived guanxi shows positive relations towards subordinates on leadership behavior in family business

\begin{tabular}{|c|c|c|c|c|c|c|c|c|c|c|c|}
\hline \multicolumn{12}{|c|}{ Dependent variables } \\
\hline \multicolumn{2}{|c|}{ Ingratiation } & \multicolumn{2}{|c|}{ Exchange } & \multicolumn{2}{|c|}{ Rationality } & \multicolumn{2}{|c|}{ Assertiveness } & \multicolumn{2}{|c|}{$\begin{array}{l}\text { Upward } \\
\text { appeal }\end{array}$} & \multicolumn{2}{|c|}{ Coalition } \\
\hline M1 & M2 & M1 & M2 & M1 & M2 & M1 & M2 & M1 & M2 & M1 & M2 \\
\hline
\end{tabular}

\begin{tabular}{l|c|c|c|c|c|c|c|c|c|c|c|c}
\hline Gender & .008 & -.013 & .001 & -.017 & .031 & .008 & -.085 & -.096 & -.063 & -.086 & -.007 & -.031 \\
\hline Seniority & $-.175^{*}$ & -.112 & $-.167^{*}$ & -.112 & $-.152^{*}$ & -.08 & -.067 & -.032 & -.079 & -.007 & -.128 & -.055 \\
\hline Job Function & -.001 & -.013 & .013 & .003 & $.156^{*}$ & $.143^{*}$ & .07 & .064 & .013 & .001 & .065 & .052 \\
\hline Industry & -.016 & -.08 & $.128^{*}$ & .073 & $.123^{*}$ & $.051^{*}$ & -.022 & -.057 & $.113^{*}$ & .04 & $.116^{*}$ & .041 \\
\hline Job level & .016 & .097 & -.069 & -.051 & -.051 & -.027 & $-.235^{* *}$ & $-.223^{* *}$ & .013 & 011 & .059 & .083 \\
\hline
\end{tabular}

\begin{tabular}{l|c|c|c|c|c|c|c|c|c|c|c|c}
\hline $\begin{array}{l}\text { Perceived } \\
\text { Guanxi }\end{array}$ & & $.397^{+*+}$ & & $.346^{+*+}$ & & $.45^{*+*}$ & & $-.319^{*+*}$ & & $-.453^{+* *}$ & & $.462^{+* *}$ \\
\hline F values & 2.209 & 11.96 & 3.329 & 10.368 & 2.482 & 15.849 & 3.946 & 6.155 & 1.176 & 14.454 & 1.727 & 15.858 \\
\hline $\mathrm{R}^{2}$ & .018 & .166 & .034 & .145 & .022 & .212 & .043 & .118 & .003 & .196 & .011 & .212 \\
\hline$\Delta \mathrm{R}^{2}$ & & .148 & & .112 & & .190 & & .075 & & .193 & & .201 \\
\hline
\end{tabular}

Note. $\mathrm{N}=332 ;{ }^{*} p<.05 ;{ }^{* *} p<.01 ;{ }^{* * *} p<.001$ 


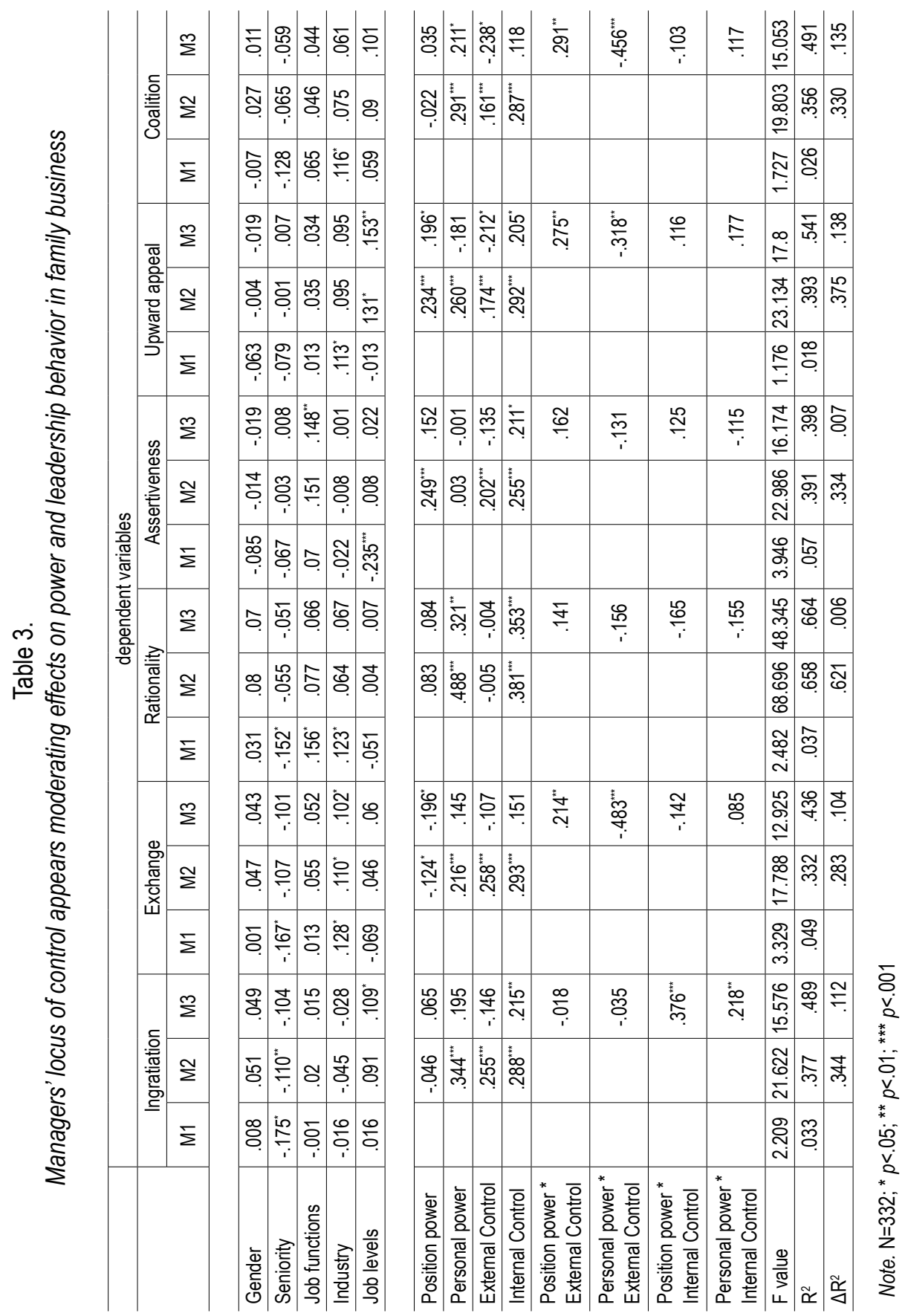




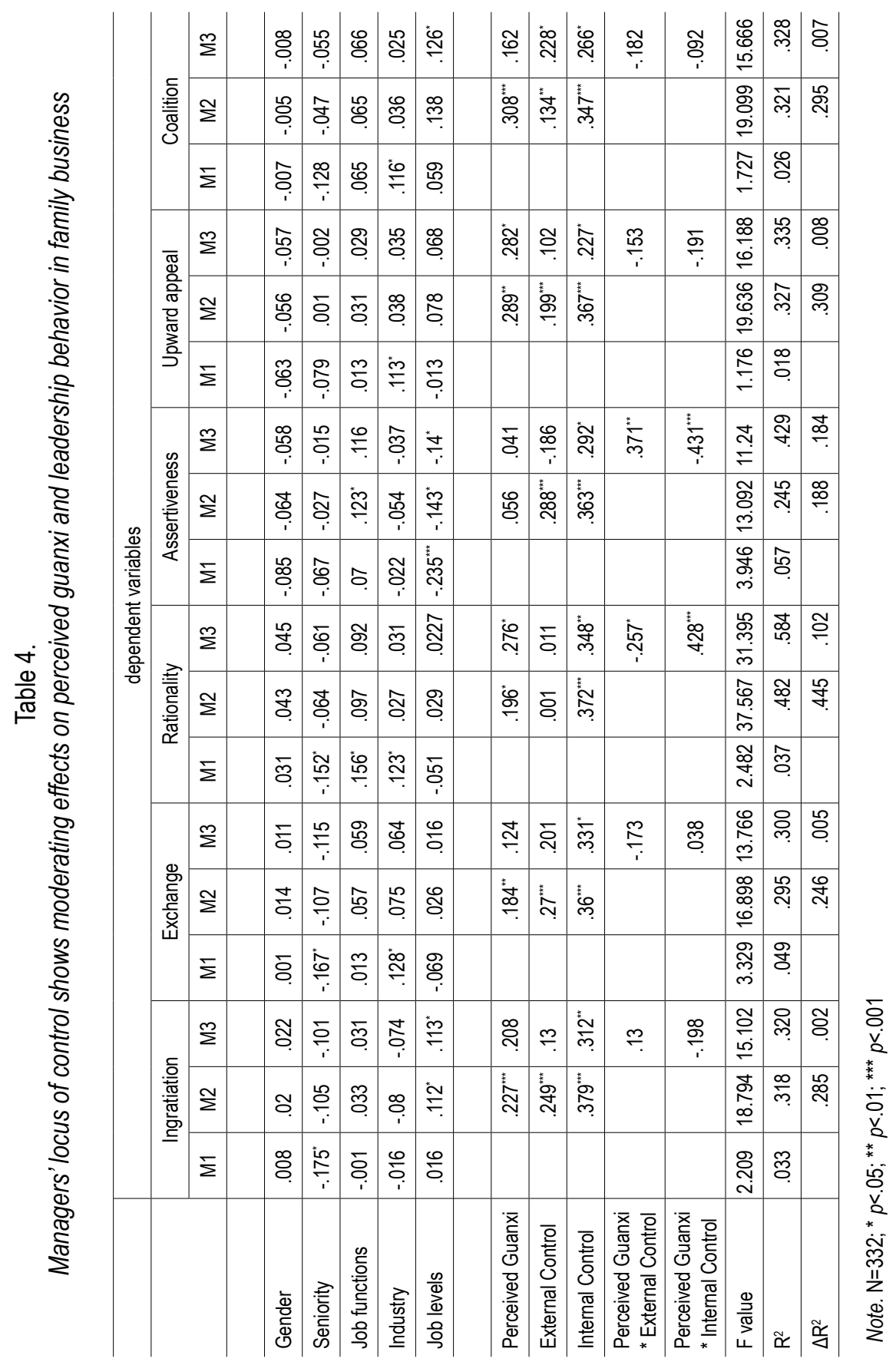




\section{REFERENCES}

Arregle, J., Hitt, M. A., Sirmon, D. G. and Very, P. 2007. "The development of organizational social capital: Attributes of family firms." Journal of Management Studies 44(1):73-95.

Baron, R. M. and Kenny, D. A. 1986. "The moderator-mediator variables distinction in social psychological research: Conceptual, strategic, and statistical considerations." Journal of Personality and Social Psychology 51(6):1173-1182.

Bernardi, R. A. 2011. "The relationships among locus of control, perceptions of stress and performance." Journal of Applied Business Research 13(4):1-8.

Boone, C. and Hendriks, W. 2009. "Top management team diversity and firm performance: Moderators of functional-background and locus-of-control diversity." Management Science 55(2):165-180.

Brass, D. J. and Burkhardt, M. E. 1993. "Potential Power and Power Use: An Investigation of Structure and Behavior." Academy of Management Journal 36:441-470.

Brisset, M., and Nowicki, S. 1973. "Internal versus external control of reinforcement and reaction to frustration." Journal of personality and social psychology 25(1): 35-44.

China Credit Information Service, 2010. "Top 10 largest business groups for 2010, showing that the financial industry almost taking all away while the technology industry is giving all up!" http://news. cnyes.com/Content/20101027/KCCBQBM8AQETQ.shtml.

Chung, H. M. 2012. "The role of family management and family ownership in diversification: The case of family business groups." Asia Pacific Journal of Management, doi:10.1007/s10490-012-9284-x.

Conger, J. A. and Kanungo, R. N. 1987. "Toward a behavioral theory of charismatic leadership in organizational settings." Academy of Management Review 12:637-647.

David, V. D. and Stanley, B. S. 1989. "Personality and job performance: Evidence of incremental validity." Personnel Psychology 42:25-36.

Durbin, A. J. 2001. Leadership: research findings, practice and skills (3rd ed.). Houghton Mifflin Company.

Finkelstein, S. 1992. "Power in top management teams: Dimensions, measurement, and validation." Academy of Management Journal 35:505-538.

Furnham, A. and Drakeley, R. J. 1993. "Work locus of control and perceived organizational climate." The European Work and Organizational Psychologist 3(1):1-9.

French, J. R. P. and Raven, B. 1959. The bases of social power. D.Cartwright, Studies in Social Power (ed.). Institute for Social Research, Ann Arbor, MI.

Gold, T., Guthries, D. and Wank, D. 2002. Social Connections in China. Cambridge: Cambridge University Press.

Haybatollahi, M. and Gyekye, S. A. 2012. "The moderating effects of locus of control and job level on the relationship between workload and coping behavior among Finnish nurses." Journal of Nursing Management. doi: 10.1111/j.1365-2834.2012.01474.x

Hinkin, T. R. and Schriesheim, C. A. 1989. "Development and Application of New Development and Application of New Scales to Measure the French and Raven (1959) Bases of Social Power." Journal of Applied Psychology 74:561-567. 
Holpp, L. 1994. "Applied empowerment." Training 31(2):39-44.

Hwang, K. K. 1987. "Face and favor: the Chinese power game." American Journal of Sociology 92:944974.

Jacobs, J. B. 1979. "A preliminary model of particularistic ties in Chinese political alliances: Kan-ch'ing and Kuan-hsi in a rural Taiwanese township." The China Quarterly 78:237-273.

Judge, T. A. and Bono, J. E. 2001. "Relationship of core self-evaluation traits-self-esteems, generalized self-efficacy, locus of control, and emotional stability-with job satisfaction and job performance: A meta analysis." Journal of Applied Psychology 86(1):80-92.

Kellermanns, F. W. and Eddleston, K.A. 2004. "Feuding families: When conflict does a family firm good." Entrepreneurship Theory and Practice 28(3):209-228.

Kipnis, D., Schmidt, S. M. and Wilkinson, I. 1980. "Intraorganizational influence tactics: explorations in getting one's way." Journal of Applied Psychology 65(4):440-452.

Lee, D. J., Pae, J. H. and Wong, Y. H. 2001. "A model of close business relationships in China (guanxi)." European Journal of Marketing 35(1/2):51-69.

Lee, D. Y. and Dawes, P. L. 2005. "Guanxi, trust, and long-term orientation in Chinese business markets." Journal of International Marketing 13(2):28-43.

Martin, R., Thomas, G., Charles, K., Epitropaki, O. and McNamara, R. 2005. "The role of leader-member exchanges in mediating the relationship between locus of control and work reactions." Journal of Occupational and Organizational Psychology 78:141-147.

May, D. R., Gilson, R. L. and Harter, L. M. 2004. "The psychological conditions of meaningfulness, safety and availability and the engagement of the human spirit at work." Journal of Occupational and Organizational Psychology 77(1):11-37.

Meyer, J. P., Stanley, D. J., Herscovitch, L. and Topolnytsky, L. 2002. "Affective, continuance, and normative commitment to the organization: A meta-analysis of antecedents, correlates, and consequences." Journal of vocational behavior 61(1):20-52.

Miller, D. and Le Breton-Miller, I. 2006. "Family governance and firm performance: Agency, stewardship, and capabilities." Family Business Review 19(1):73-87.

Ng, T. W. and Feldman, D. C. 2011. "Locus of control and organizational embeddedness." Journal of Occupational and Organizational Psychology 84(1):173-190.

O'Reilly, C. A. 1977. "Personality-job fit: Implications for individual attitudes and performance." Organizational Behavior and Human Performance 18(1):36-46.

Pierce, L.W. and Dunham, R.B. 1987. "Organizational commitment: Pre-employment propensity and initial work experiences." Journal of Management 13(1):163-178.

Podsakoff, P. M., MacKenzie, S. B., Lee, J. Y. and Podsakoff, N. P. 2003. "Common method biases in behavioral research: A critical review of the literature and recommended remedies." Journal of Applied Psychology 88(5):879-903.

Robbins, S. P. 2001. Organizational Behavior (9th ed.). New Jersey: Prentice-Hall.

Rosenberg, M. and Pearlin, L. 1962. "Power-orientations in the mental hospital." Human Relations 15:335-349. 
Rotter, J. B. 1954. Social learning and clinical psychology. Englewood cliffs, NJ: Prentice-Hall.

Rotter, J. B. 1966. "Generalized expectancies for internal versus external control of reinforcement." Psychological Monographs: General and Applied 80(1):1-27.

Schriesheim, C. A. and Hinkin, T. R. 1990. "Influence tactics used by subordinates: a theoretical and empirical analysis and refinement of the Kipnis, Schmidt, and Wilkinson subscales." Journal of Applied Psychology 75(3):246-257.

Spector, P. E. 1982. "Behavior in organizations as a function of employee's locus of control." Psychological bulletin 91(3):482-497.

Spector, P. E. 1988. "Development of the work locus of control scale." Journal of occupational psychology 61(4):335-340.

Taormina, R. J. and Gao, J. H. 2010. "A research model for Guanxi behavior: Antecedents, measures, and outcomes of Chinese social networking." Social Science Research 39(6):1195-1212.

Tsai, H. T., Yeh, S. P. and Wu, T. J. 2011. "The use of governmental-firm guanxi under different market conditions for Taiwanese hospitality firms invested in China." Actual Problems of Economics 12(2):4-11.

Tsai, H. T., Wu, T. J. and Yeh, S. P. 2013. "Exploring the guanxi type of managers in family businesses from the perspective of power based and leadership behaviors." South African Journal of Economic and Management Sciences. (Forcecoming)

Yang, C. F. 2000. Psychocultural foundations of informal groups: The issues of loyalty, sincerity, and trust. In L. Dittmer, H. F. and Lee, P.N.S. (Eds.), Informal Politics in East Asia (pp 85-105). NY: Cambridge University Press.

Yang, M. M. 1994. Gifts, favors and banquets: The art of social relationships in China. NY: Cornell University Press.

Yukl, G. 2002. Leadership in Organizations (4th ed.). NJ: Prentice Hall.

Yukl, G. and Falbe, C. M. 1990. "Influence tactics in upward, downward, and lateral influence attempts." Journal of Applied Psychology 75:132-140.

Zhang, X. and Li, G. 2003. "Does guanxi matter to nonfarm employment?" Journal of Comparative Economics 31(2):315-331.

Zhuang, G., Xi, Y. and Tsang, S. L. 2010. "Power, conflict, and cooperation: The impact of guanxi in Chinese marketing channels." Industrial Marketing Management 39:137-149.

DR. TunG-Ju Wu is a lecturer in the college of business administration at HUAQIAO University in China. He received the PhD of Business Management at National Sun Yat-sen University, Kaohsiung, Taiwan. His research interests are Strategy Management, Organizational Behavior, Human Resource Management, and Guanxi issue in Chinese society. In the last three years, he has published five international journal papers and seven international conference papers. 
DR. Hsien-TANG Tsal is a Professor of Management at the Department of Business Management, National Sun Yat-sen University, Kaohsiung, Taiwan. He received his Ph.D. degree from Krannert School of Management, Purdue University, USA, in 1986. His research interests include the areas of management sciences, sustainable development, quality engineering, food safety management, tourism management, etc. His work has appeared in Management Science, IIE Transaction, EJOR, JORS, Health Policy, etc.

Dr. Shang-Pao Yeh is a Professor in the Department of Tourism at I-Shou University located in Kaohsiung, Taiwan. He received a MBA in Finance and Accounting from Northrop University, a Master in Public Administration from University of Southern California, and a Doctor of Management from Webster University. His current research interests include knowledge management, organizational behavior, human resource management, and e-learning.

Dr. Shang -Pao Yeh is the corresponding author in this paper.

RECEIVED: 11 August 2013.

ACCEPTED: 25 February 2014.

PUBLISHED ONLINE: 11 June 2014. 